\title{
Being a victim of medical error in Brazil: an (un)real dilemma
}

\author{
Vitor Silva Mendonça, Eda Marconi Custódio \\ Department of Psychology of Learning, Development, and Personality, University of São Paulo, \\ Brazil
}

\begin{abstract}
Medical error stems from inadequate professional conduct that is capable of producing harm to life or exacerbating the health of another, whether through act or omission. This situation has become increasingly common in Brazil and worldwide. In this study, the aim was to understand what being the victim of medical error is like and to investigate the circumstances imposed on this condition of victims in Brazil. A semi-structured interview was conducted with twelve people who had gone through situations of medical error in their lives, creating a space for narratives of their experiences and deep reflection on the phenomenon. The concept of medical error has a negative connotation, often being associated with the incompetence of a medical professional. Medical error in Brazil is demonstrated by low-quality professional performance and represents the current reality of the country because of the common lack of respect and consideration for patients. Victims often remark on their loss of identity, as their social functions have been interrupted and they do not expect to regain such. It was found, however, little assumption of error in the involved doctors' discourses and attitudes, which felt a need to judge the medical conduct in an attempt to assert their rights. Medical error in Brazil presents a punitive character and is little discussed in medical and scientific circles. The stigma of medical error is closely connected to the
\end{abstract}

Correspondence: Vitor Silva Mendonça, Institute of Psychology, Department of Psychology of Learning, Development, and Personality, University of São Paulo, Av. Prof. Mello Moraes, 1721, Cidade Universitária, São Paulo, CEP 05508-030SP, Brazil.

Tel.: +55.113.091.4355.

E-mail: vitor.pospsico@bol.com.br

Key words: Medical error; suffering; victim, Brazil.

Contributions: VSM, literature survey, writing the review, corrections; EMC, editing the review, corrections.

Conflict of interest: the authors declare no potential conflict of interest.

Funding: this work was supported by the Brazilian National Council for Scientific and Technological Development.

Received for publication: 30 June 2015.

Revision received: 28 February 2016.

Accepted for publication: 29 February 2016.

This work is licensed under a Creative Commons AttributionNonCommercial 4.0 International License (CC BY-NC 4.0).

(C) Copyright V. Silva Mendonça and E.M. Custódioet al., 2016

Licensee PAGEPress, Italy

Health Psychology Research 2016; 4:5408

doi:10.4081/hpr.2016.5408 value and cultural judgments of the country, making it difficult to accept, both by victims and professionals.

\section{Introduction}

Medical error is a theme that has been addressed since antiquity, as the medical profession is one of the oldest in the world, and errors among those who practice it are also an age-old problem. In Egypt and in Ancient Rome, the punishment for the doctor's error advocated these professionals' good civil liability (Gomes, Drumond \& França, 2001).

The social role of this profession has roots in the power of healing and salvation, with a training that was strongly marked by the search for infallibility, and influenced by the hegemonic message that errors with patients are unacceptable. However, in modern times, with the advent of new technologies, the medical field has been evolving, and the diversity of medical errors has accompanied this movement. This situation fits in with physicians' social role and has led to a series of discussions on a new profile for these professionals, in which caution and patient care are central themes (David \& Sureau, 2006).

The literature on medical error indicates that, in fact, the number of victims has grown exponentially, and not only in Brazil. In the United States in 2000, an average of 98,000 deaths occurred per year as a result of errors (Kohn, Corrigan \& Donaldson, 2000). In France in 2008, about 190 thousand cases were submitted for analysis based on the possibility of medical error (Grange \& Papilon, 2008).

The number of complaints against doctors began to increase in the 1970 s in the United States. A North American study stated that in 1960 , patients in the United States voiced one complaint per year for every 100 physicians; by 1985, this number had increased to 18 complaints. Compensations followed the same trend, increasing from 60 million dollars to 5 billion dollars in the same time period. Also in the United States, an $11 \%$ increase was recorded in the number of doctors punished with suspension, restriction, or cancellation of professional practice, in just one year in the 1990s (Hiatt, 1992).

In 2013 , a British study reported that $16 \%$ of hospitalized patients were affected by some type of medical error, and that half of these errors are attributed to mistakes in the procedures carried out prior to medical practices (Weerakkody et al., 2013). Countries like France have developed procedures for stricter control, prevention, and punishment of medical error. Based on a study in 2008, one each ten hospitalized patients were affected by medical error; thus the French government developed a regulatory framework to protect the victims and to reduce the number of errors, mainly by prohibiting excessive working hours for doctors (Grange \& Papilon, 2008).

In Brazil, the discussions on medical error are recent, and do not have figures on the precise number of deaths caused by medical error, as no specific body is responsible for this control. Nonetheless, this situation is cause for concern, due to the incidence of complaints filed against medical attitudes, and the human and material damage that could be avoided. 
Some studies give a general overview of medical errors in Brazil. In the State of Goiás, patients and their families filed 2293 complaints between 2000 and 2006. Of these, 31.6\% were related to professional incompetence, i.e. complaints related to dissatisfaction with the results of the treatment, the death of the patient, and other medical errors (Fujita \& Santos, 2009). In another Brazilian study, researchers carried out a review of publications produced on medical error in two databases of interest to the health field. They found that the literature produced on the subject in the last ten years was scant, with an average of just over one publication per year (Mendonça, Delamanha, Carvalho \& Custodio, 2013). By 2013, Brazilian medical practices had 400,000 registered professionals, with a rate of 2 doctors per 1000 inhabitants (Scheffer, 2013). Between 2000 and 2004, the Regional Council of Medicine of the State of São Paulo (Cremesp) investigated complaints against doctors in that state in the Brazilian legal system, and they found a total of 353 decisions handed down in the civil sphere, and 23 in the criminal sphere. Of this total, approximately $46 \%$ of the decisions were in the patient's favor, with compensation being awarded for moral damage. The highest level of condemnation applied to the doctors accused, i.e. the act practiced by these professionals inflicted pain or suffering on the victim (Mansur \& Oliveira, 2006).

Medical councils in Brazil are organized by state, and their goal is to supervise professional ethics throughout the territory under their jurisdiction and, at the same time, to judge and to discipline the medical class, prioritizing the perfect ethical performance of medicine and its legal exercise (Udelsmann, 2002).

Although the Brazilian Code of Medical ethics, which was approved by the Federal Council of Medicine (CFM) in September of 2009, Resolution CFM no. 1931/09, does not directly explain the concept of medical error, it does declare in Article 1 of Chapter III that doctors are forbidden to ...cause damage to the patient, by act or omission, characterized by incompetence, recklessness or negligence (Conselho Nacional de Saúde Brazil, 2009).

However, we find highlighting the main concepts of medical error important as they include the guidelines governed by the competent world health bodies and the scientific works that have been developed. Based on this, it is possible to affirm that the victims of medical error are not taken into consideration in this type of discussion and investigation. Brazilian studies have placed more emphasis on the number of complaints recorded by the Regional Councils of Medicine (CRMs), the disciplinary procedures applied, and the reported doctors' profiles, and they provide some important rules about what doctors need to avoid to prevent error and for their patients not to suffer annoyances (Fujita \& Santos, 2009; Gomes et al., 2001; Udelsmann, 2002).

Interestingly, the victims of medical errors do not feature much in the scientific literature, and there is a lack of scientific investigation into the self-perceptions of medical error victims. No voice has been given to these people in the attempt to understand the phenomenon of being a victim of error and the suffering involved. In this article, it is possible to understand what being a victim of medical error in Brazil is like, and to investigate the circumstances that are imposed in this process, based on the experience and narratives of patients who have been victims.

The phenomenological-existential perspective used in this study, it is guided at the thought of Heidegger, Husserl follower. This perspective has emerged as a challenge to the traditional mode of Western thought, questioning whether modern science could make human life more meaningful. The thrust of the investigation should go of things and of the problems, taking as the starting point of knowledge back to the things themselves: a return to experience (Heidegger, 1995; Husserl, 2006).

This conception search perform a deep reflection about the experience, which then would allow achieving the essence of knowledge, thinking always in the understanding of man and the world, from its very existence. The phenomenology elects its own way of being of man as its base, i.e. search make available what through the metaphysics remained in hiding for the think (Heidegger, 1995; Husserl, 2006; Critelli, 1996).

\section{Materials and Methods}

\section{Participants and setting}

This qualitative study was conducted with 12 patients, who were victims of medical errors in Brazil. Seven of the participants were female, and five were male. The victims were aged between 25 and 72 years, at the time of the interviews. According to the proposal of this work, did not have specific selection criteria for participation. The only criterion required was proof of medical error by an ordinary court of law, or by the Regional Council of Medicine, which would allow for better scientific rigor in the data and the research. The interviews took place during 2012, in the cities of São Paulo and Rio de Janeiro.

\section{Interview}

Thinking about the possibility of creating a space for the participants to talk about their experiences and give their views on the phenomenon, the oral reports were decided to use as the methodological resource. A semi-structured interview was used, with the following opening request: Tell me about your experience, beginning when you discovered the medical error until today. This request enabled the participants to reflect more deeply. While the participants were narrating, the researcher sometimes asked short questions seeking information about the theme that, for various reasons, the participants might not have reported at first.

\section{Analysis and procedure}

The narratives of the participants' experiences were recorded with the participants' consent. Subsequently the interviews were transcribed and analyze in order to articulate the possibilities of comprehension, based on our search for meaning. The content obtained into thematic groups or units of meaning were organized, which medium revealed some possibilities of the phenomenon, based on each participant's experiences as a victim of medical error (Critelli, 1996).

The research was registered with and approved by the Ethics Committee of the University of São Paulo. This study also followed Resolution no. 196/96 of the National Health Council, which regulates research involving human beings in Brazil, in order to guarantee the research participants' rights, and their consent were obtained through an Informed Consent Form that explained the study's objectives, procedures, and benefits (Conselho Nacional de Saúde Brazil, 1996).

The real names were not used for people nor for the institutions involved in the cases described in this study to protect their privacy, and in respect for the participants, and for the Brazilian regulations on research involving human beings. The fictitious names of the participants are the names of Nobel® Peace Prize winners.

\section{Results}

\section{Characterization of the victims and of medical errors}

The stories and cases presented here are the result of hours of narratives by the participants who were willing to report on a phase of life 
that many of them still remember with trauma, suffering, and sadness for having to go through such a situation. Each victim's experience has its importance because the art of narrating a fact of life is adversely affected by excessive explanation and a lack of interest in perpetuating the experience.

Table 1 shows the type of medical error that each patient was involved in and the health service in which the medical procedure was performed. Readers should absorb these recorded experiences and freely interpret them, thus we have avoided too much explanation. Also, it was not programmed in a logical sequence, but in the ease of being lost in clouds while on a ladder, bound for the center of the earth, and nothing and nobody could stop them, not even death (Benjamin, 1994). But this can be avoided whenever a story is recounted or narrated, like the reports presented in this study. The participants' modes were maintained of expression throughout this report.

\section{The concept of medical error according to the victims themselves}

In almost all the concepts formulated on medical errors, a similarity was founded as to its negative connotation, as something that causes harm to the victim. In addition, the victims always reported seeing the professional as the cause: the guilty party who should have done the job correctly, but who did not. For example: It's like a tidal wave, because the sickness itself is already a tragedy. Then, when you go through a sickness for which you have to have surgery, the expectation of a cure is very great. It will end there, you trust your health or the health of a loved one to the hands of a professional. When you realize that this has not been done, due to the recklessness or negligence of that professional, it's as though a wave has swept away your hope, your high expectations. [Jimmy].

Likewise, Barack reported: Medical error is irresponsibility. I think it's a lack of empathy with the patient. You don't know your patient. And you're there, but not caring. I think that medical error is when you are [the professional is] there just because you're doing it for the money, and not for the profession, for ethics and for love.

\section{Being a victim of medical error in Brazil}

People's descriptions of their own experiences are of fundamental importance, because only they can develop and give meaning to the whole constitution of the experience (Benjamin, 1994): It's horrible. I feel like a different person because I can no longer work, because I used to work. I am no longer normal for work. And even if another person values me, I don't value myself any more. I don't think I am capable of doing what I did, before the error. I am not the same person. [Teresa].

Alva also shared her feelings: It is bad, it's terrible. You're left with a feeling of helplessness because you can't do much by yourself, the most you can do is accept that you have limitations and try and work within them? Within the limitations. And that's bad for a human being who is more active. Let's put it like that. [Alva]

The position of the victim is unique and inherent to each discourse. The feelings of helplessness, failure, not belonging, and losing their identity because they do not feel capable of producing what they did before the error, are some of the characteristics of the victims' descriptions about living after a medical error.

In fact, some victims use other narratives to present what it is like to be victim, but Shirin's discourse still fits with what has been presented so far because she realizes the importance of going beyond the experience of error. Some might believe she has become a different, and better person. She reported her experience thus: I think that I to go through these difficulties to become the person I am today. I was a very hard person, even as a child. I was very hard, everything with me was iron and fire, and I had to become a little more flexible, so yes, I had to go through some difficulties, yes, I needed to rely on visits to a psychologist to measure my mood. Yes, I needed to sometimes get away from something that I really liked, so that I could find something I really love, you know?

\section{Reactions of medical professionals involved with the error}

The clinical attitude relates to the ability to see, hear, capture, finetune, and respond to the patient from the patient's perspective so that the patient's conditions of life, environment, family relations, beliefs, and convictions are present on both sides of the relationship. Based on this, one could say that the doctor has a way of looking, conducting, and reacting to the most diverse situations that occur in the work environment (Mello Filho \& Burd, 2010), i.e. each professional has a clinical attitude, and their reactions when faced with medical errors will also differ from one individual to another.

Each professional has a way of behaving when faced with a medical error, but the fact that medical professionals, in general, find it difficult to assume an error is not surprising. And such was the case for the doctors involved here, according to the victims. None of the professionals was able to offer help or take responsibility for the error of their own free will, forcing the victims to assert their rights through the Brazilian courts.

According to the doctor, it was the nursing team's fault. When he

Table 1. Identification of the victims and description of cases.

\begin{tabular}{|c|c|c|c|}
\hline Victim & Age, years & Description of medical error & Type of health service \\
\hline Teresa & 61 & Underwent cataract surgery and went blind & Public service \\
\hline Jane & 56 & Responsible doctor not present at the labor & Public service \\
\hline Shirin & 30 & Wrong limb operated on & Private service \\
\hline Ellen & 55 & Inadequate dermatological procedure & Private service \\
\hline Dalai & 33 & Prosthesis placed wrongly & Private service \\
\hline Nelson & 72 & Application of anesthesia in incorrect place & Private service \\
\hline Barack & 36 & Wrong organ operated on & Private service \\
\hline Jimmy & 39 & Surgical material left inside the body & Public service \\
\hline Betty & 25 & Wrong limb operated on & Public service \\
\hline Alva & 66 & Prosthesis placed wrongly & Public service \\
\hline Emily & 44 & Need for surgery ignored by the doctor & Public service \\
\hline Martin & 38 & Indication of medication to which the patient was allergic & Public service \\
\hline
\end{tabular}


arrived at the surgical center, the leg was already prepped. He only did the surgery. But, my father said, You were in charge of the surgery. You should have checked everything. Isn't that your responsibility? [Shirin]

Likewise, Martin reported: I tried, but I couldn't talk to him Ithe doctor responsible for the error]. I went to the institution twice, but I was never able to, and even the institution, they wouldn't give me any support. I even tried the customer services, but I was really badly treated. That was when I went to my lawyer to find out what to do.

\section{The types of health services and their relationship with medical error}

Initially, the conjuncture of medical error is not restricted to the Brazilian public health service. Here, five out of the twelve cases occurred in private services, as shown in Table 1. Thus, there is a direct relationship between the type of service and the occurrences of medical errors. However, which has seen is that the public service still leaves something to be desired in various sectors and situations. Jane said: For me, sickness portrays the health of the country. The health of the country is in the ICU [intensive care unit]. A dreadful disregard, unprepared doctors, unqualified persons, persons of ill repute.

Emily expressed similar feelings: I think that they should have more capacity and interest in public service. And although we may be poor, we are still human beings, and they need to give more attention and assistance to the people, because the public service is an embarrassment.

Jane and Emily leave no doubt in their discourses that the care provided by public health service employees leave a lot to be desired, not only when it comes to their dealings with users patients, but also in the professional training and ethics, transmitting an image of disregard and contempt for the citizens.

In the public service, there is also a difficulty in scheduling appointments, tests, and surgery, due to the high demand, which results in a certain slowness in the practice of the system. This circumstance is very familiar to the population, who is used to it and has become resigned, feeling that there is nothing they can do nothing.

In Brazil, the public services are offered free of charge to the population, and everyone has the right to access them. The government, from taxes, funds this type of service. Private services, on the other hand, are paid for by the individuals who use each service.

Another recurring problem is the comparison of the public to the private services. A large portion of the population relies on services that users pay for directly, and, of course, the security of having direct access to a professional who is a specialist in his or her field. This fact lends more credibility to the health service of the private sector, in the eyes of the population (Starfield, 2002).

Dalai expressed his opinion thus: My doctor who fixed the error said: No, at that hospital, no, it's very good, but it is a profit-making institution, I don't work there. He was speaking of a private hospital of renown in Brazil. 'I only operate at this, this and this hospital, and preferably at the [name of a private hospital]. There they are committed'. And it really was: you could see the concern of the nurses, from the time you entered to the time you were discharged, everything is different, it's different, it's a different level of commitment to the human being. It should be the same everywhere, but unfortunately it's not, particularly in the public system.

\section{Discussion}

People feel the profound emotional experiences in an individual way, particularly issues involving suffering in the area of health and disease. Often, new and unexpected things cause destabilization and con- fusion at the start, but as people progress and then face and overcome this fear, they acquire a certain resistance and, in the future, they realize how profound the experience was, to the point of sharing and perceiving its importance for their process of growth and personal learning, so that, from these traumatic experiences, they have a better understanding of themselves, in order to achieve better emotional functioning (Mendonça, 2009).

The stigma in relation to medical error is something still little discussed, however it can be observed that a victim has struggled to be accepted by her or by society. The stigma is all that doesn't sit well with the frame of social expectations about particular individual. All societies define categories about the attributes considered normal, natural and common human being, and when this does not occur the stigma and the stigmatized individual, whose actual social identity includes any attribute that thwarts the expectations of normality. What is easily seen in Brazilian society in relationship to the victim of medical error (Goffman, 2004).

The theoretical framework of the phenomenological-existential perspective was of great value to the victims experience favoring the understanding of the phenomenon, from its existence, his way of being in the world and the way in which each answer and still responds to what was presented in the case, the medical error. According to this perspective, the error would not be overcome by the fact of being part of the essence of that person who lived and experienced medical error in his own life. It must be acknowledged that public health in Brazil needs to improve in several aspects. After twenty-five years of existence, the Single Health System, the Brazilian national health system, still presents challenges to be overcome, such as those the research participants mentioned. The population has grown and the proportional logic of health professionals still needs to be better managed and distributed. The demand has grown so fast that the quantity and quality of equipment and manpower are now insufficient for a more humanized care (Mendes, 2013; Menicucci, 2014).

It can highlight some possible causes of medical error in Brazil. The first is the training and medical education that has been the subject of criticism on account of the need for change. Today, undergraduate education is facing a scenario of deterioration, motivated by the proliferation of schools of medicine (Scheffer, 2013). The hegemonic model has a training that places too much emphasis on the biological aspect and the fragmentation of knowledge, in addition to lacking suitable stimulus for the development of autonomy and the capacity for analysis, judg ment, and evaluation (Gomes \& Rego, 2011). The second cause is the excessive workload and poor working conditions that create circumstances that can sometimes lead to medical error (Barbosa, 2007). Third, emotional fatigue and poor health conditions are also influential factors in the causes of error. Night shifts and the psychological pressure to put into practice the acquired knowledge mean that doctors have an exhausting routine, which is a key factor in the development of burnout (Soares et al., 2012; Straub, 2005; Waterman et al., 2007).

Involvement in a medical error may promote a higher incidence of depression, emotional stress and burnout in the professional; hence the importance of communication with the patient and other professionals, given that the impact of the error on the doctor's life is harmful and, at the same time, prone to new cases and thus more damage (Schwappach \& Boluarte, 2008; Waterman et al., 2007; Wu, 2000).

Avoiding the reduction of patient confidence, preventing the increase of anxiety in the patient, and the possibility of facing a legal process are the reasons that lead some physicians not to admit to their mistakes (Carvalho \& Vieira, 2002).

Many doctors fear that the new social roles in contemporary society, which is increasingly questioning and knowledgeable about its rights, may cause doctors to become more anxious to protect their patients and to provide evidence of their professional conduct, which can lead 
to the loss of the essence of the medical profession (Murr, 2010).

Some international institutions have developed special agencies to ascertain the quality of patient care. In 1999, the United States created the Agency for Healthcare Research and Quality. In 2002, at the 55th World Assembly of the World Health Organization, a Global Alliance was formed for patients' clinical safety (Chehuen Neto, Sirimarco, Visoná de Figueiredo, Barbosa \& da Silveira, 2011). In France, also in 2002, the National Office for Compensation of Medical Accidents was created with the purpose of working for people with health problems, and for the quality of the health care system (Grange \& Papilon, 2008).4 Brazil still lacks initiatives such as these, which prioritize better quality, more humanized care between doctors and patients, and support better care for victims of medical errors.

The study has some limitations. The sample represented a little part of all the many medical errors occurred in Brazil. In this way, there are not representative of all cases of medical errors nationwide. But this study represented a progress in Brazilian science, because none research has a subject to victims of medical errors and their narratives. Another limitation was to get access to victims, because of the difficulty imposed by lawyers and the fear of reliving the problem.

\section{Conclusions}

The data supplied by this research reinforce the need for greater commitment and supervision of medical errors that have been occurring in the Brazilian territory, with the purpose of looking at this theme with a constructive bias, in an attempt to reduce its occurrence, promoting health for doctors, and offering greater security for patients.

\section{References}

Barbosa, G.A. (2007). A saúde dos médicos no Brasil. Brasília: Conselho Federal de Medicina.

Benjamin, W. (1994). Magia e técnica, arte e política. São Paulo: Brasiliense.

Carvalho, M., \& Vieira, A.A. (2002). Erro médico em pacientes hospitalizados. Jornal de Pediatria, 78, 261-268.

Chehuen Neto, J.A., Sirimarco, M.T., Visoná de Figueiredo, N.S., Barbosa, T.N., \& da Silveira, T.G. (2011). Erro médico: a perspectiva de estudantes de medicina e direito. Revista Brasileira de Educação Médica, 35, 5-12.

Conselho Nacional de Saúde Brasil. (1996). Diretrizes e normas regulamentadoras de pesquisa envolvendo seres humanos. (Resolution $\mathrm{n}$. 196, 10 October 1996).

Conselho Nacional de Saúde Brasil. (2009). Código de ética médica. (Resolution n. 1931, 17 September 2009).

Critelli, D.M. (1996). Analítica do sentido: uma aproximação e interpretação do real de orientação fenomenológica. São Paulo: EDUC Brasiliense.

David, G., \& Sureau, C. (2006). De la sanction à la prévention de l'erreur médicale. Paris: Lavoisier.

Fujita, R.R., \& Santos, I.C. (2009). Denúncias por erro médico em Goiás. Revista da Associação Médica Brasileira, 55, 283-289.

Goffman, E. (2004). Estigma: notas sobre a manipulação da identidade deteriorada. Rio de Janeiro: Guanabara.

Gomes, A.P., \& Rego, S. (2011). Transformação da educação médica: é possível formar um novo médico a partir de mudanças no método de ensino-aprendizagem? Revista Brasileira de Educação Médica, $35,557-566$.

Gomes, J.C.M., Drumond, J.G.F., \& França, G.V. (2001). Erro médico. Montes Claros, MG: Ed. Unimontes.

Grange, P., \& Papilon, F. (2008). Erreurs médicales. Paris: Nil.

Heidegger, M. (1995). Ser e tempo. Petrópolis: Vozes.

Hiatt, H. (1992). Medical malpractice. Bulletin of the New York Academy of Medicine, 68, 254-264.

Husserl, E. (2006). Ideias para uma fenomenologia pura e para uma filosofia fenomenológica. São Paulo: Ideias \& Letras.

Kohn, L.T., Corrigan, J.M., \& Donaldson, M.S. (2000). To err is human: building a safer health system. Washington: National Academy Press.

Mansur, N.S., \& Oliveira, R.A. (2006). O médico e a justiça. São Paulo: Conselho Regional de Medicina do Estado de São Paulo.

Mello Filho, J., \& Burd, M. (2010). Psicossomática hoje. Porto Alegre: Artmed.

Mendes, E.V. (2013). 25 anos do sistema único de saúde: resultados e desafios. Estudos Avançados, 27, 27-34.

Mendonça, V.S. (2009). Sofrendo entre quatro paredes: relatos de mães acompanhantes dos filhos hospitalizados. Revista Electrónica de Psicología Política, 7, 12-29.

Mendonça, V.S., Delamanha, R.L., Carvalho, J.B., \& Custodio, E.M. (2013). Erro médico no Brasil: um panorama das publicações entre os anos de 2003 a 2012. In: Anais do II Congresso Ibero-Americano de Psicologia da Saúde e III Congresso Luso-Brasileiro de Psicologia da Saúde: 2013 jul 4-6; Faro, Portugal.

Menicucci, T.M.G. (2014). História da reforma sanitária brasileira e do sistema único de saúde: mudanças, continuidades e a agenda atual. História, Ciências, Saúde-Manguinhos, 21, 77-92.

Murr, L.P. (2010). A inversão do ônus da prova na caracterização do erro médico pela legislação brasileira. Revista Bioética, 18, 31-47.

Scheffer, M. (2013). Demografia médica no Brasil. São Paulo: Conselho Federal de Medicina and Conselho Regional de Medicina do Estado de São Paulo.

Schwappach, D.L.B., \& Boluarte, T.A. (2008). The emotional impact of medical error involvement on physicians: a call for leadership and organisational accountability. Swiss Medical Weekly, 138, 9-15.

Soares, L.R., Lopes, T.M.O., Silva, M.A.O., Ribeiro, M.V.A., de Almeida, M.P. Jr, Silva, R.A., ..., Chen, L.C. (2012). Burnout e pensamentos suicidas em médicos residentes de hospital universitários. Revista Brasileira de Educação Médica, 36, 77-82.

Starfield, B. (2002). Atenção primária: equilíbrio entre necessidades de saúde, serviços e tecnologia. Brasília: UNESCO/ Ministério da Saúde.

Straub, R.O. (2005). Psicologia da saúde. Porto Alegre: Artmed.

Udelsmann, A. (2002). Responsabilidade civil, penal e ética dos médicos. Revista da Associação Médica Brasileira, 48, 172-182.

Waterman, A,D., Garbutt, J., Hazel, E., Dunagan, W.C., Levinson, W., Fraser, V.J., \& Gallagher, T.H. (2007). The emotional impact of medical error on practicing physicians in the United States and Canada. Joint Commission Journal On Quality And Patient Safety, 33, 464-476.

Weerakkody, R.A., Cheshire, N.J., Riga, C., Lear, R., Hamady, M.S., Moorthy, K., Darzi, A.W., ..., Bicknell, C.D. (2013). Surgical technology and operating-room safety failures: a systematic review of quantitative studies. BMJ Quality and Safety, 22, 710-718.

Wu, A.W. (2000). Medical error: the second victim. British Medical Journal, 320, 726-727. 